\title{
PROCEDURAL DUE PROCESS: THE TWO- EDGED SWORD THAT THE UNTRAINED SHOULD NOT UNSHEATH
}

\section{H. Rutherford Turnbull III}

Ann P. Turnbull

Bonnie Strickland

University of North Carolina at Chapel Hill

The issue of procedural due process is examined in this article by first analyzing the associated legal requirements of P.L. 94-142 and then identifying the "trig. gers" which professionals and parents can use to initiate a due process hearing. Problems and unresolved issues associated with interpreting and applying due pro. cess safeguards in terms of initiating, conducting, and governing the hearing and hearing officer are discussed. The concluding section of the article identifies specific training implications and creeds of due process hearing officers.

Procedural due process rests on a fundamental notion of fairness: that is, the citizen has a right to protest before the government takes any action that may adversely affect him. In the case of the handicapped child, the right is to protest actions of the state education agency (SEA) or the local education agency (LEA). Without a right to challenge the school's potentially discriminatory practices, children would find that their substantive right to receive a free appropriate education would be depressingly empty.

Procedural due process is also a constitutional requirement under the Fifth and Fourteenth Amendments to the Constitution, which forbid the government to deprive a person of his life, liberty, or property without due process of law. As applied to the education of handicapped children, this means that no handicapped child can be deprived of an education (the means for acquiring property as well as life and liberty in the sense of self-development) without being entitled to exercise his right to protest what happens to him.

The success of the right-to-education laws reflects a belief commonly held by lawyers and educators alike: fair procedures will tend to produce acceptable, correct, and fair results.

The purpose of this paper is (a) to examine the legal requirements, including the ambiguous ones, of due process as set forth in PL 94-142, identifying the triggers that professionals or parents may pull to force each other to comply with the law by initiating a due process hearing, and (b) to highlight the training implications of due process procedures for various affected people, particularly hearing officers. 


\section{Legal Requirements}

There are five major components of the due process requirements of PL 94-142. These are

1. due process hearings

2. independent educational evaluations

3. written notice to parents

4. parental consent

5. surrogate parents

Each of these components will be discussed separately.

\section{Due Process Hearings}

It is a common misconception of procedural due process under PL 94-142 that only parents or guardians of handicapped children may initiate a due process hearing against the child's local education agency (LEA). In fact, however, the LEA itself is empowered to call for due process hearings. It is convenient to deal first with the parents' rights and then the LEA's.

The LEA must give the parents, guardian, or surrogate of a handicapped child an opportunity to present complaints relating to any matter concerning the child's identification, evaluation, or placement or his right to a free, appropriate public education (Sec. 615[b] [1] [E] / ${ }^{1}$. A parent or guardian who files a complaint with an LEA is entitled to an opportunity for an impartial hearing. The LEA must inform the parents about any available low-cost or free legal aid in the geographical area (Sec. 121a.506 of the regulations).

As noted above, the right to a due process hearing is not limited to the child's parents or other representatives. Under Sec. $121 \mathrm{a} .504$ and Sec. 121a.506, an LEA may also initiate a due process hearing on its proposal or refusal to initiate or change the identification, evaluation, or placement of a handicapped child or the free, appropriate public education provided to him. For example, a classroom teacher who suspects that a child is handicapped may refer him to the LEA's special services committee for a multidisciplinary evaluation. The parent, however, must give consent when a child is being evaluated for initial placement in a special education program. If parents refuse to consent to evaluation, and the LEA's staff believes that an evaluation should be obtained, the LEA may initiate a due process hearing to challenge the parents' decision to withhold consent to a multidisciplinary evaluation. Thus, due process hearings allow all parties involved - parents and professionals - to hold each other accountable. 
Once a complaint is presented, the public agency must appoint an impartial hearing officer to conduct the hearing. The officer may not be an employee of the agency and may not have any personal or professional interest that would conflict with his objectivity (Sec. 121a.507). A person who otherwise qualifies to conduct a hearing is not considered an employee of the agency solely because he is paid by the agency to serve as a hearing officer. The local school board and employees of the state school board are not impartial hearing officers under PL 94-142 (Com. pochiaro v. Califano [Civ. No. H-78-64, D. Conn., May 18, 1978] ).

At the hearing, both parties may be advised by counsel or by experts in the education of handicapped students; present evidence, examine and cross-examine witnesses; subpoena witnesses and documents; make arguments; receive a written or electronic verbatim of the hearing; and receive a written account of the hearing officer's findings of fact.

An appeal from the initial decision to the state agency and then to state or federal district court may be taken by the child's representatives, by the LEA, or by any other aggrieved party.

'References to sections of PL 94-142 are cited in the text: e.g. (Sec. 615 [b] [1] [E] |. All such references to sections begin with a 6 . References to the regulations implementing PL 94-142 are also cited: e.g. (Sec. 121a.506). All sec. tions of the regulations begin with 121 .

\section{Independent Educational Evaluations}

The child's parents or other representatives are entitled to an independent (nonagency) educational evaluation of the child. The law stipulates that evaluation consists of "procedures used to determine whether a child is handicapped and the nature and extent of the special education and related services that the child needs." The procedures are to be used selectively with an individual child and exclude basic tests administered to or procedures used with all children in a school, grade, or class. A qualified examiner not employed by the public agency responsible for educating the child is entitled to do the evaluation. A qualified person is one who has met certification, licensing, registration, or other such requirements of the SEA in the area in which he provides special education or related services (Sec. 121a.12).

LEAs must, upon request, tell parents where they may have independent educational evaluations made. Under some circumstances, the evaluation is to be made at public expense, the LEA either paying the full cost of the evaluation or insuring that the evaluation is otherwise provided free to the parent. A parent has the right to a free, independent evaluation if the hearing officer requests one for use in a due process hearing or if the parent disagrees with the evaluation made by the public agen- 
cy. However, if the agency, in a hearing that it initiates, can prove that its evaluation was appropriate, the parent may be required to pay for the new evaluation. When a parent obtains an independent evaluation at his own expense, the agency must take it into consideration as a basis for providing the child with an appropriate education or as evidence in a due process hearing, or both (sec. 121a.503).

\section{Written Notice}

The LEA must give the child's parents or other representatives prior written notice whenever it proposes or refuses to initiate or change the child's identification, evaluation, or placement. The notice must include the following components (Sec. 121a.505):

1. a full explanation of all the procedural safeguards available to the parents

2. a description of the action proposed or refused by the agency, an explanation of why the agency proposes or refuses to take the action, and a description of any options the agency considered and the reasons why those options were rejected

3. a description of each evaluation procedure, test, record, or report the agency uses as a basis for the proposal or refusal

4. a description of any other factors that are relevant to the agency's proposal or refusal

It also requires that the notice be

1. written in language understandable to the general public

2. provided in the native language of the parent or other mode of communication used by the parent, unless it is clearly not feasible to do so If the native language or other mode of communication of the parent is not a written language, the SEA and LEA must take steps to insure

1. that the notice is translated orally or by other means to the parent in his or her native language or other mode of communication

2. that the parent understands the content of the notice

3. that there is written evidence that the requirements (of oral translation and the parent's understanding/ have been met

\section{Parental Consent}

Parental consent must be granted voluntarily and in writing before an agency conducts the preplacement evaluation of the handicapped child or initially places a child in a program that provides special education and related services (Sec. 121a.504).

Consent, in this context and in all others, means that (a) the parent has been fully informed in his native language, or in another suitable 
manner of communication, of all information relevant to the activity (such as evaluation) for which consent was sought; (b) the parent understands and agrees in writing that the activity may be carried out; $(c)$ the consent describes the activity and lists the records (if any) that will be released and to whom; and (d) the parent understands that he gives his consent voluntarily and may revoke it any any time.

If a parent refuses to consent when his consent is required, the parties must first attempt to resolve the conflict by complying with any applicable state law. If there is none, then the agency may initiate a due process hearing. Should the hearing officer rule in favor of the agency, the parent's refusal will be overruled, and the agency may evaluate or place the child, notifying the parents of its actions so that they may appeal (Turnbull \& Turnbull, 1978, p. 177).

\section{Parent Surrogates}

If a child's parents are unknown or unavailable, or if the child is a ward of the state, the LEA must appoint a surrogate to represent the child in all matters related to the provision of a free, appropriate public education (Sec. 121a.514). The surrogate must have the skill to represent the child and may have no conflict of interest that would interfere with this capability.

\section{Triggers for a Due Process Hearing}

As stated previously, the due process safeguards of PL 94-142 extend significantly beyond the specific due process hearing. The hearing, however, is the primary device for insuring the fairness of decisions and the accountability of all parties. A key issue in effectively implementing the procedures for due process hearings is identifying the circumstances under which hearings may be initiated by parents and LEAs.

One way of analyzing PL 94-142 and its accompanying regulations is in terms of the rights that handicapped children have in their dealings with the SEA and LEA and the concomitant duties that those agencies have to the children. The rights-duties analysis identifies the occasions when either a student or his representatives or an LEA may claim that his or its rights have been denied and that he or it is entitled to a due process hearing. The rights-duties analysis also clarifies the manner in which PL 94:142 and its regulations work to insure that handicapped children and LEAs have both rights and duties. For example, five of the six major legal principles of PL 94-142 insure that certain procedures will occur: zero reject assures that the child will be included in a free appropriate public educational program; nondiscriminatory evaluation assures that he will 
be fairly assessed; appropriate education insures that he will be educated in an individualized and meaningful way; least restrictive placement assures that he will not be unjustifiably segregated; and parental participation insures that the parent will be given a voice in the child's education. All these procedures involve both rights and duties.

PL 94-142 addresses each of these five principles by setting out the procedure or process by which the LEA must educate a handicapped child. The law also states that if the agency does not comply with the required procedure or process, the child may have an opportunity to challenge the school by requesting a due process hearing. Likewise, if the child's parents do not conform to certain procedures or processes so that the LEA may educate the child in the manner the law requires, the agency itself may have an opportunity to challenge the parent by requesting a due process hearing. The specific triggers of due process - organized according to the five principles of zero reject, nondiscriminatory evaluation, individualized instruction, least restrictive environment, and parental participation - are presented below. Unless otherwise indicated, the child's parents or other representatives may file a due process hearing with respect to all of the following triggers.

\section{Zero Reject}

1. Sec. 121a.300: SEA failure to insure compliance with dates-certain and ages-certain requirement

2. Sec. 121a.302: SEA and LEA failure to comply with free residential placement requirement

3. Sec. 121a.303: SEA and LEA failure to provide for proper functioning of hearing aids

4. Sec. 121a.305: SEA and LEA failure to provide for program options, including art, music, home economics, and vocational education

5. Sec. 12la.306: SEA and LEA failure to provide nonacademic services

6. Sec. 121a.307: SEA and LEA failure to provide physical education

7. Sec. 121a.320,321,323, and 324: SEA and LEA failure to comply with service priorities requirement

8. Sec. 121a.401: SEA failure to insure that children placed by LEA in private schools (a) receive special education and related services and (b) have all the rights of handicapped children served by the public schools

9. Sec. 121a.403: If parents place the child in private school, SEA or LEA failure to provide services to the child according to Sec. 121a.450-.460, but either the SEA or the LEA may initiate a due process hearing on the appropriateness of an LEA program or the question of financial responsibility 
10. Sec. 121a.451: If a child is in private school by parent placement, SEA failure to provide for the child's participation in federally funded programs (failure to assure special education or related services) or SEA failure to insure that LEAs comply with Sec. 121a.452-.460

11. Sec. 121 a.452, .453 , and .455: LEA failure to (a) provide special education and related services to handicapped children in private school, (b) provide such children a genuine opportunity to participate in public programs, (c) provide them with special education and related services comparable in quality, scope, and participation to those for handicapped children in public programs, and (d) use funds consistent with requirements for nondiscrimination in public programs (per Sec. 121a.456, .457, .458, .459, and .460)

\section{Nondiscriminatory Evalutation}

1. Sec. 121a.530: SEA or LEA failure to select and administer testing and evaluation materials and procedures that are not racially or culturally discriminatory

2. Sec. 121a.531: SEA or LEA failure to do individualized evaluation (per Sec. 12la.532) before initial placement

3. Sec. 121a.532: SEA or LEA failure to comply with evaluation procedures before initial placement

4. Sec. 121a.533: SEA or LEA failure to comply with placement procedures, including interpreting evaluations

5. Sec. 121a.534: SEA or LEA failure to review the child's individualized education program (IEP) and perform reevaluation every three years or more often if warranted or requested by parent

\section{Individualized Education Programs}

1. Sec. 121a.341: SEA failure to provide for IEPs for handicapped children in private schools

2. Sec. 121a.342: SEA or LEA failure to comply with deadline for IEP development (at the beginning of the school year)

3. Sec. 121a.343: SEA or LEA failure to initiate the meeting, have the conference when required, or review the IEP annually

4. Sec. 12la.344: SEA or LEA failure to have all required parties at the IEP meeting

5. Sec. 121a.345: SEA or LEA failure to provide for parent's participation at the IEP meeting

6. Sec. 121a.346: SEA or LEA failure to write an IEP with proper content

7. Sec. 121a.347: SEA or LEA failure with respect to handicapped children in private school to initiate or conduct an IEP meeting, have 
private school participation at the meeting, or review IEPs annually

8. Sec. 121a.348: SEA or LEA failure with respect to children enrolled in both public and private schools to have an IEP meeting or have private school participation at the meeting

9. Sec. 121a.349: SEA or LEA failure to provide special education and related services as required by the child's IEP

\section{Least Restrictive Environment}

1. Sec. 12la.550(b): SEA or LEA failure to comply with the LRE requirement

2. Sec. 121a.551: SEA or LEA failure to insure a continuum of alternative placements, including separate education and resource or itinerant teachers

3. Sec. 121a.552: SEA or LEA failure to make an annual determination of placement, based on the child's IEP, as close as possible to the child's home; make program alternatives available to the extent necessary to implement the child's IEP; place the child in the school he would attend if he were not handicapped, unless his IEP calls for a different placement; or consider any potential harmful effect of placement on the child or the quality of services he needs

4. Sec. 121a.553: SEA or LEA failure to provide or arrange for nonacademic and extracurricular services and activities in the LRE

5. Sec. 121a.554: SEA failure to implement the LRE for handicapped children in public and private institutions (other than schools)

\section{Parent Participation}

1. Sec. 121a.561: SEA failure to notify parents concerning the adoption of the state plan and amendments and major identification, location, and evaluation activities

2. Sec. 121a.562: SEA or LEA failure to grant parents access to records concerning their children, upon request, and before the IEP meeting or due process hearing at which the issue is the child's identification, evaluation, or placement, and to comply with the required elements of parent access

3. Sec. 121a.563: SEA or LEA failure to keep record of parental access

4. Sec. 12la.566: SEA or LEA failure to charge reasonable fees for copying of records (not excessively high fees)

5. Sec. 121 a.567, .568, .569, and .570: SEA or LEA failure to amend records at parent's request

6. Sec. 121a.573: SEA or LEA failure to destroy information not needed to serve the child, at parent's request 


\section{INTERPRETING AND APPLYING THE DUE PROCESS SAFEGUARDS}

When the senior author of this article was a member of the Procedural Safeguards Committee of the Regulation Input Conference that developed most of the concept papers and many of the draft regulations that became the foundation for the final regulations adopted by the Department of Health, Education and Welfare on August 23, 1977, he was struck by several facts that may help explain why the procedural safeguard's regulations are so difficult to interpret and apply and, thus, why training hearing officers and others is so important.

First, the conference was broadly representative of many affected constituencies. These were regular educators, special educators, SEA and LEA administrators, advocates for handicapped children, advocates for children whether or not handicapped, university faculty from a wide range of disciplines (school and educational psychology, special education, school administration, and law), teacher union representatives, private consultants, and others. Many delegates also came prepared to make a case for the regulations to set out one rule but not another. It was predictable that the final regulations would represent a sort of vegetable soup - a little of this, a little of that, and plenty of broth.

Second, almost every racial or ethnic minority group was represented. So, too, were all geographic regions of the country. Thus, Anglo-Americans from the rural Midwest were grouped with SpanishAmericans from the nation's most populous cities. Again, compromise was predictable.

Finally, there were precious few attorneys, particularly in the group that drafted the procedural safeguards regulations. Although lawyers' concerns with procedures often complicate the regulatory process and impede the swift (as well as capricious) administration of statutes, those concerns nevertheless are particularly important when drafting regulations that call for administrative or quasijudicial hearings such as the due process hearings under PL 94-142.

It is regrettable, in retrospect, that there were not more attorneys involved in drafting the due process regulations and that they and the Department's Office of General Counsel's and Office of Civil Rights' attorneys did not spell out in greater detail the elements of the due process hearing. Although this failure may be explained and perhaps excused in light of who was invited to participate in the conference, the failure nevertheless is causing a great number of problems in understanding and applying the due process regulations. 


\section{Initiating the Hearing}

Is there a time when it is too late to file a hearing request? The act and the regulations contain no statute of limitations.

Sec. 121 a.506 provides that a parent or LEA may initiate a due process hearing; but the regulation does not provide for a mechanism to initiate the hearing. How may one be requested - orally or in writing? To whom should the request be addressed - the LEA's superintendent, school board chairman, or other person? And what should the recipient do with the request - notify the hearing officer or others, in writing or orally, and confirm to the petitioner that he has taken that action?

\section{Conducting the Hearing}

There are, as well, a host of questions concerning the hearing itself. What procedures should be followed? Which party presents its case first? Is there a right to make an opening statement? Is there a right of the petitioner to make a reply to the other side's final statement? Is there even a right to a final statement? In short, how will the hearing officer conduct the hearing so that it will be orderly, time efficient, and informative?

What rules of evidence apply? Those that federal or state courts in that jurisdiction follow? Or a more relaxed set of rules, one that allows for the admission of evidence and the examination of witnesses under rules that deviate from those of the ordinary civil or administrative hearing?

Although counsel clearly is permitted to every party at the hearing, and counsel's role normally is understood by everybody in administrative or civil hearings (it is to advise, to present the client's case, to attack the other side's case, and to argue), it is not at all clear from the regulations what the role is of "individuals with special knowledge or training with respect to the problems of handicapped children." Is it to serve as expert witnesses? As advisers to counsel for the purposes of helping present the client's case and impeaching the evidence of the other side (especially the other side's expert witnesses)? To argue the case for the party if there is no counsel to do so?

What about errors made by the hearing officer, such as accepting inadmissible evidence (once one decides which rules of evidence, if any, apply), making prejudicial statements (those that indicate that the hearing officer has made up his mind before hearing the case), failing to allow a party to present its whole case leven if part of it is redundant and cumulative of evidence he already has admitted), or seemingly assisting one party in presenting its case las by questioning one party's witnesses 
in a friendly manner but obviously cross-examining another party's witnesses)? Will the rule of "harmless error" be applied by the SEA appeal hearing officer? (The rule of harmless error prohibits a decision from being reversed or modified on appeal if the error did not or could not have had an impact on the decision.)

Sec. 121 a. 508 of the regulations forbid evidence from being admitted if it has not been disclosed to one of the parties by the other at least five days before the hearing. What, then, constitutes disclosure - telling the other side who the witnesses are and what they will say and informing the other side which documents will be offered as evidence and what those documents contain? Or simply listing the witnesses and documents? Is the hearing officer, prior to the hearing, entitled to discover the evidence that each party proposes to use? Would that be potentially prejudicial? What should he do if one party discloses its case to him but the other does not and later objects to the prior disclosure? What if the other party does not know of the disclosure?

Do the rules of trial discovery apply? The regulations are silent and imply that they do not. But the state may have an Administrative Procedures Act that authorizes discovery. What law applies if federal and state law are in conflict?

Although the regulations (Sec. 121a.508) require the LEA to transmit the hearing officer's findings and decisions to the state advisory council on special education after deleting personally identifiable information, it is unclear under the regulations whether those records are accessible to the general public or even to the child's parents.

The regulations have serious shortcomings with respect to another very important matter: the authority of the hearing officer to enter orders and enforce his decisions. While providing for a hearing, for an impartial hearing officer, and for decisional finality, they do not address the nature of the decision.

For example, is the hearing officer restricted only to considering the issue as presented to him by the party filing the appeal? Take the case of a parent who seeks a hearing and then alleges that the LEA failed to perform a proper evaluation of his child, offering evidence that indicates in what respects the evaluation was improper, inadequate, or incorrect. Does the hearing officer decide only whether the evaluation was not proper, adequate, or correct? Or does he particularize his findings, stating the deficiencies in detail? May he order the LEA to perform an evaluation that corrects the deficiencies, or may he order only a proper, adequate, or correct evaluation? What power does he have to enforce his decision (or decision plus recommendation in the form of a particularized decision)? Assume the LEA reevaluates the child without fully satisfying the hearing officer's particularized findings (and recommendation). What power 
does he have to prevent further inadequacies? Clearly, he has no statutory or regulatory enforcement power; he cannot resort to such familiar judicial remedies as injunctions, civil penalties for contempt, or assessment of damages.

The problem of defining the scope of the hearing officer's decisionmaking and enforcement powers is aggravated in the case of the child's individual education plan, or IEP, which requires at least annual review (whereas evaluation is required only every three years), placement, and entitlement to "related services," both of which are likely to change from time to time as the child's condition and age change.

It becomes even more important to have specific and enforceable orders when the issue is the appropriateness of the child's education. While PL 94-142 defines and guarantees an appropriate education, it does not guarantee that the child will receive the most appropriate education. Accordingly, a narrowly drawn finding of fact and decision by a hearing officer on the issue of appropriate education may serve little purpose except to instruct the parties that, on the evidence presented, the child is or is not receiving an appropriate education. Unless the hearing officer also enters a decision setting forth what appears to him to be an appropriate education, the LEA or the parents are likely to have subsequent hearings on the issue of appropriateness.

Clearly, there is a potential for a truculent LEA to abide by a perhaps unenforceable decision by making only the barest defensible effort at compliance while simultaneously avoiding taking action to satisfy the spirit of the decision and forestall any future due process hearings by the same parent on similar or the same grounds. The LEA that chooses to take such an approach may find that it wears the parents down, sapping them of their will and ability (including economic and physical ability) to resist. On the other hand, it may encourage parents and child advocates to organize a well-financed wholesale attack.

To forestall the costly, inefficient, and minimally productive repetitious hearings about the same child and his evaluation, IEP, placement, or appropriate education, it is useful for the parents and LEA to stipulate in advance of the hearing the issues, facts, and acceptable remedies and to inform the hearing officer thereof. Although the doctrine of res judicata does not apply (to prevent the same issue involving the same parties from being tried again), there will be a common sense of estoppel - that is, the parties will be reluctant to bring up the same issues again and again.

In addition to setting forth the facts regarding possible denial of a child's legal rights, the party requesting the hearing may also seek particular and general relief. In his allegations, he would be well advised to allege violations that cover the broadest provable grounds - for example, 
that the child was improperly diagnosed and therefore, his IEP is inappropriate, his placement is erroneous, and he is, by reason of all the above, being denied an appropriate education. In his prayers for relief, he then should seek specific relief for each complaint and, to be on the safe side, seek other legal and equitable relief as may be appropriate and warranted. In short, a broad-based challenge and a petition for relief are devices that might assure that the hearing officer hears and decides upon all or most of the relevant issues surrounding the child's rights to a free, appropriate public education, thereby reducing the likelihood that there will be multiple hearings involving the same parties.

\section{Governing the Due Process Hearing Officer}

Two obvious due process safeguard issues surround the hearing officer himself. One concerns his impartiality and qualifications to serve. The regulations (Sec. 121a.507) provide that the hearing officer shall be impartial: he may not be employed by the LEA or other agency involved in the education or care of the child, and he may not have a personal or professional interest that conflicts with his objectivity.

It is a rather easy thing to prove partiality if the hearing officer is an employee of the agency. It is quite another to prove it if the party believes that the hearing officer has conflicting personal or professional interests. And it is still another matter to attempt to avoid having a case heard by a hearing officer whose record of decisions indicates that he is pro-LEA or pro-student. (Like lawyers who practice regularly before civil or criminal courts, parties in due process hearings will come to know who the friendly hearing officers are, and they will legitimately seek to have their cases heard by those officers and no others.) Finally, it is by no means clear what the regulations mean when they require an LEA or SEA to keep a list of hearing officers that includes a statement concerning the qualifications of each of them. The term "qualifications" could refer solely to their being qualified by reason of being impartial. It also could mean that the hearing officer is professionally qualified by reason of professional training and expertise, having attended training programs for due process hearing officers, or other qualifying characteristics.

The regulations clearly are deficient with respect to characterizing impartial and qualified hearing officers. They do not permit any party to file a motion or any more informal challenge to the impartiality or qualifications of the hearing officer; they do not say whether a hearing officer may refuse to hear a case or even remove himself from a case after it begins if he discovers that he may no longer be fairly said to have no personal or professional interest that would interfere with his impartiality; and they leave completely open the question of whether a party at the 
hearing may appeal solely on the grounds that the hearing officer was not impartial or qualified.

There are several good rules of thumb for selecting unbiased hearing officers: (a) the SEA or LEA might ask consumer organizations to nominate persons; (b) the SEA and LEA could give those organizations the right to approve or object to hearing officers; $(c)$ hearing officers should be professionally unaffiliated with the agency involved in the due process hearing or with a consumer agency (for example, present or former school employees from one LEA should not serve as officers for LEA hearings although they may preside in hearings involving state or local mental health services or institutions in other jurisdictions); and (d) hearing officers should not reside or work in the jurisdiction involved in the hearing. These guidelines are designed to insure that, in general, the list of hearing officers will be prepared in a way that will eliminate the more obvious objections to impartiality. One procedure that might be even more effective is to direct the SEA and consumer organizations to the state or local bar association's young lawyers' section as a source for names of lawyers who could serve. In addition, labor arbitrators or other persons experienced in hearing procedures could be hired; the services of post-secondary education faculty could be enlisted; or distinguished local citizens could be asked to hear cases in jurisdictions where they have no professional or personal interests. Of course, the agency that appoints a hearing officer may always remove him from its approved list.

A second issue concerning both the LEA and the hearing officer focuses on the regulation (Sec. 121a.512) that requires the LEA to insure that a final decision is reached in the hearing within forty-five days after the agency receives a request for a hearing. As noted above, it is unclear who is authorized to receive a request on an agency's behalf. Assume that the request is received by someone not in a position to call the hearing and that the person does not immediately notify the authorized person (whoever that might be, and arguably it could be the hearing officer himself or some other LEA employee). It is clear that there has already been an infringement of the forty-five-day rule. Assume further that the hearing officer hears the case on the thirtieth day after the request has been received (thereby allowing about three weeks for the parties to prepare their cases and comply with the five-day disclosure rule), but he does not render his decision within the next fifteen days, and neither party has requested and received an extension of the forty-five-day period. Must there then be a hearing on the extension of the period, or will a conference of the parties suffice? Usually, hearing officers and judges may not act ex parte, that is, without giving both sides an opportunity to be heard. In addition, what can be done to require the hearing officer to comply with the regulation? There are no procedures in the regulations that 
enable any party to require a hearing officer to do his duty in a timely manner. Apparently, the only recourse with respect to such an officer is to remove him, the question then being whether he should be removed after hearing the case, in which event another hearing before another officer would be required, or after finally reaching his decision. And what happens to the child while the hearing officer dallies with the parties?

In addition, because hearing officers usually have other obligations, LEAs and SEAs must pay careful attention to the problem of when to hold hearings and how to keep a backlog of cases from developing. Judicial ad. ministration techniques that help process cases rapidly through the trial courts may be useful. These include regularly scheduled hearing dates, prehearing conferences between the parties and the hearing officer, easy access to school records and evaluations by LEA and consumer expert witnesses before hearings, prehearing stipulations of facts and issues of law, flexibility in granting a limited number of postponements, and the willingness of the parties to use affidavits in lieu of live testimony.

\section{Additional Issues}

There are other issues involving due process hearings that, for the purposes of this paper at least, do not bear as directly on the training of due process hearing officers and the adequacy of the regulations as the issues discussed above. They deal, for example, with the possibility that LEAs may keep a double set of records on the child: one that the parents and other monitoring agents have access to and another informal set for school use only. Likewise, they involve the right of a litigant in federal court to have access to records of all children in an LEA. Such a right has been granted in Mattie T. v. Holladay (F. Supp., N.D., Miss., 1978), a class action against an LEA in which the court ordered that the plaintiffs may discover those records as long as the personally identifying information in them is deleted.

There are, as well, a host of issues concerning the suspension or expulsion of handicapped children. Does the federal law mean that an LEA may not suspend or expel handicapped children who violate student conduct regulations? If the effect or purpose of the suspension or expulsion is to change a student's placement (rather than doing so by IEP and placement decisions /, the school may be enjoined from suspending or expelling the student until the placement decision is made in the ordinary course of complying with PL 94-142 (Stuart v. Nappi, 433 F. Supp. 1235 [D. Conn., 1978], decision on order granting preliminary injunction, accord, Howard S. v. Friendswood Independent School District, 454 F. Supp. 634 [S.D. Tex., 1978] ). Where the suspension or explusion has resulted in a child's being denied free, appropriate public education as 
guaranteed by PL 94-142, two school districts have entered into consent agreements providing for the child to be readmitted or given compensatory education (in a community college) at the school's expense (Donnie R. v. Wood [No. 77-1360, D.S.C., consent decree entered August 22, 1977] and Lopez v. Salida School District [C.A. No. C-73078, Dist. Ct., Denver Cty., Colo., Jan. 20, 1978] ). Finally, emotionally disturbed children are claiming that they must be treated in the same way as mentally retarded children in due process hearings on issues of discipline $(J$. v. Klein [No. 77-2257, E.D. Pa., filed June 28, 1977]).

There are two obvious points to the foregoing discussion of the procedural safeguards. The first is that the federal regulations are inadequate in themselves to answer many of the questions that have been raised. Whether state education or administrative procedures laws furnish answers is hard to say at this time.

The second is that there is no substitute for well-trained hearing officers. When thoroughly schooled on the procedures to be followed in the hearings, the substance of case law, the applicable federal and state statutes and regulations, the nature and organization of the LEA involved in the hearing, the general characteristics of various handicapping conditions, and the general abilities of educators to respond to those disabilities, hearing officers will be likely to make more informed and more correct (less reversible or objectionable) decisions with less deliberation. The implications of the due process regulations for training hearing officers is the subject of the next section.

\section{TRAINING IMPLICATIONS}

The full implementation of due process safeguards requires significant new knowledge and the development of new skills by many affected people. They include LEA and SEA personnel, school board attorneys and members, parents of handicapped students, preservice educators, faculty in departments of education at colleges and universities, attorneys, and hearing officers. Their needs are likely to depend on the extent of their background knowledge about handicapped children and special education practices and law and on their future involvement in due process proceedings. Thus, training models need to be individually designed for the specific target audience that will receive the training.

One of the most important audiences (in terms of assuring that due process hearings lead to fair decisions) consists of the hearing officers. It is noteworthy that the regulations for implementing PL 94-142 require only that the hearing officer be impartial, that is, that he be free from conflict of interest and that he not be an employee of the agency (Sec. 
121a.507). There is no requirement that the hearing officer be knowledgeable in legal proceedings or in educational issues associated with providing appropriate instruction to handicapped students. Thus, it is likely that a hearing officer could clearly meet the requirement of impartiality yet be ill prepared to execute his duties because he lacks important knowledge.

\section{Training Issues}

Three pertinent issues that must be resolved before training the hear. ing officers include sponsorship, method of delivery, and cost. Since the SEA has the ultimate responsibility of insuring that officers are qualified, decisions pertaining to these issues should be made or orchestrated at the SEA level.

Sponsorship. A variety of alternatives exists for sponsoring training of due process hearing officers. Frequently, the training is done by the SEA. In these instances, a potential conflict could exist since the officers are being prepared to hear grievances that could be filed against the SEA. An example of such a conflict was reported to the authors by a hearing officer trainee who attended an SEA-conducted training program. This officer reported that the simulated activities all involved decisions made in favor of the LEA or SEA and against the parent. The extent of this type of bias may be infrequent and certainly cannot be generalized to all LEAs; however, the potential conflict of interest on the part of the SEA in delivering training should not be overlooked.

The SEA can contract with outside agencies and individuals to provide training. A necessary consideration is: What skills should a trainer possess in order to prepare hearing officers adequately to execute their responsibilities? Essentially, trainers need expertise in both the education of handicapped students (in determining characteristics, evaluation, and program alternatives) and in legal requirements and procedures (PL 94-142, other applicable state law, state legislation, court cases, and trial advocacy and process). Because of this dual set of skills and knowledge, interdisciplinary training by both educators and lawyers is appropriate. Thus, the SEA might contract with universities that could combine the resources of schools of education and law to provide interdisciplinary training. Another possibility is to contract with private consultants who combine expertise in both education and law.

Method of Delivery. In considering the method of delivering training to hearing officers, issues such as timing, location, and scope of training should be considered. In regard to timing, it is a common practice for states to provide training to hearing officers on an annual basis. Certain- 
ly, SEAs and LEAs are well advised to have hearing officers appointed by the beginning of the school year, if at all possible. If training is provided on only one occasion each year, some already appointed hearing officers will undoubtedly be unable to attend because of scheduling conflicts. Also, if new hearing officers are appointed throughout the school year as a result or resignments of hearing officers or heavy case loads, they will have missed the training session and will have to wait until the next annual program. SEAs might consider sponsoring two training sessions, one at the beginning of each school semester. Furthermore, packets of written information and self-instructional materials could be developed and made available to hearing officers who are unable to attend training sessions.

Ideally, training should be an ongoing rather than an isolated event that occurs only at the beginning of a hearing officer's term of service. A preliminary knowledge base is essential; however, it may be just as important for hearing officers to reconvene periodically to share their experiences in actual hearings and to engage in problem-solving related to troublesome issues on which they have questions. These sessions can contribute to systematic planning in resolving knotty problems associated with due process procedures.

The location of training is a practical consideration that could significantly influence the attendance at a training session. In large states, it is likely that training will need to be delivered on a regional basis in order to make it more convenient and thus more accessible to hearing officers.

In regard to the scope of training, variation in training needs will exist in light of the hearing officer's professional background. Table 1, which is based on a survey of North Carolina hearing officers conducted by the authors, provides a breakdown of occupations of the hearing officers according to the percentage of the total group of officers that falls into each occupation.

It is obvious that the lawyers as a group will have more expertise in legal proceedings and the rights of parties (such as rules of evidence and trial procedures) than the officers with nonlegal backgrounds. On the other hand, the educators will likely have greater expertise in educational areas, such as the characteristics of handicapped students and the organization of schools. Some hearing officers in miscellaneous occupations, such as the postmaster and the agricultural extension agent, may have a strong interest in the education of handicapped students and clearly meet the criteria of impartiality; however, they may need intensive training in all areas related to due process and appropriate education. It is dangerous, however, to make assumptions of individual needs based on 


\section{Table 1}

PERCENTAGE OF NORTH CAROLINA

HEARING OFFICERS BY OCCUPATION

Occupation

Percent of Total Group

Lawyers

31.8

Retired Educators (mostly superintendents and assistant superintendents)

Special Services Directors

College Professors

Superintendents and Assistant Superintendents

Other (housewife, postmaster, research

microbiologist, attendance counselor, Navy

officer, agricultural extension agent)

occupational groups. In order to plan systematically the scope of training needed by hearing officers, an assessment of their training needs and professional backgrounds should be made in advance.

Cost. The third training issue to be considered is cost. The training of due process hearing officers is an expensive operation. In addition to paying for the time of trainers (especially if the SEA chooses to subcontract with outside agencies or individuals), the travel and per diem subsistence expenses and an honorarium represent additional costs and should be provided to the hearing officers in order to encourage them to attend training programs. Depending upon the professional status of the hearing officer, expectations for the amount of the honorarium will vary. For example, lawyers in private practice are likely to have a set rate per hour for their time; on the other hand, hearing officers who are unemployed and thus do not have to take time away from work probably will not have an established honorarium fee. In the survey of North Carolina hearing officers, the question was posed as to what they believed to be fair compensation for serving as a hearing officer. The responses ranged from $\$ 50$ per day to $\$ 100$ per hour. The mean response was $\$ 32$ per hour. Although this question was asked in regard to serving as a hearing officer and not specifically in regard to training, the expectations for compensation are still illuminating. Despite the fact that expec- 
tations will vary, the SEA would likely create more problems than it would solve by paying officers at different honorarium rates. Thus, a common rate needs to be established. If the SEA wants to encourage and support the participation of lawyers as due process hearing officers, the honorarium for training will need to be roughly competitive with their private practice rates.

\section{CONCLUSION}

Even those special educators and others most familiar with the procedural safeguards under PL 94-142 may have tended to assume that due process is a relatively simple matter. In fact, it is not. There are numerous events that may trigger a due process hearing, providing issues over which LEAs, SEAs, and other public agencies and parents may engage in battle. Moreover, the due process regulations are, for arguably sufficient reasons, hardly a model of procedural comprehensiveness and clarity. Finally, they can become unwieldy and universally hazardous when administered by untrained people. The content and logistics of the training are suggested by this article. But even more is suggested: namely, that the Department of Health, Education and Welfare revise at least the due process hearing regulations before state practices and decisional precedents encumber them with inconsistent and potentially cumbersome interpretations.

\section{References}

Abeson, A., et al. A primer on due process. Reston, Va.: Council for Exceptional Children, 1977.

PL 94-142, 20 U.S.C. Secs. 1401, 1402, and 1411-1420, and implementing regulations. The Federal Register, August 23, 1977, pp. 42474-42518.

Turnbull, H. R., \& Turnbull, Ann P. Free appropriate public education: Law and implementation. Denver: Love Publishing Company, 1978. 